This is a post-peer-review, pre-copyedit version of an article published in Higher Education Policy. The definitive publisher-authenticated version - Jones, Glen A. (2008). Can Provincial Universities be Global Institutions? Rethinking the Institution as the Unit of Analysis in the Study of Globalization and Higher Education. Higher Education Policy, 21(4), 457-468 - is available online at http://www.palgravejournals.com/hep/journal/v21/n4/abs/hep200817a.html

\title{
Can Provincial Universities be Global Institutions? Rethinking the Institution as the Unit of Analysis in the Study of Globalization and Higher Education
}

\author{
Glen Jones
}

\begin{abstract}
The author argues that greater attention should be paid to different levels of authority in the study of globalization and higher education, especially the understructure or disciplinary units. Using Marginson and Rhoades' concept of 'Glonacal,' he argues that universities operate on local, national, and global dimensions, but also that the orientation towards these dimensions may be quite different depending on the level of authority within the higher education system. He proposes a global higher education matrix that focuses on the orientation of different levels of authority to each of the glonacal dimensions. This matrix might provide a useful framework for studying the complex, multi-layered interactions and inter-relationships associated with globalization and internationalization.
\end{abstract}

\section{Introduction}

Increasing international competition, the phenomenon of global university rankings, and the increasing use of policy tools designed to create 'world-class' research universities such as in, for example, China and Germany (Baker and Lenhardt, 2008; Mohrman, 2008) have focused attention on what are sometimes called 'global universities.' While the term is seldom precisely defined, it is clear that some institutions are global players in their ability to attract the best students and faculty, and engage in activities that have a global reach and an international impact. This phenomenon has sparked an interest in studying and understanding these global institutions.

At the same time, many of the universities that appear on these lists continue to be at least partly supported by state funds, and one can assume that these institutions continue to be asked to address the needs of the local community in which they are located, or to contribute to the economic development of the nation. Few institutions want to be, or can afford to be, completely isolated from the local dimension. But can provincial universities be global institutions?

My objective in this paper is to argue that the focus on the institution as the unit of analysis in most discussions of globalization and internationalization in higher education ignores some very important dimensions of these phenomena. I will begin by discussing a very simple case study. I will then review a series of concepts that provide the foundation for a global higher education 
matrix, a framework that might become a useful tool for understanding the complex interactions and inter-relationships associated with universities operating on a global dimension.

\section{A Tale of Two Universities}

Case 1 is a large research university with over 12,000 graduate students. It is one of the top 50 universities in the world according to most international ranking systems, ${ }^{1}$ and it is one of the top 20 under Newsweek's ranking of 'global universities' (Newsweek International Edition, 2006). The university attracts significant numbers of international graduate students and it has memoranda of understanding with universities throughout the world. The university leads its national peers in almost every recognized indicator of research activity and productivity. It attracts significant research grants in a wide range of fields. It has an extraordinary research library with a collection of more than 18 million items. The university is an active participant in the international academic labour market, recruiting and appointing faculty from leading institutions around the world. It is an institution that positions itself as one of the world's leading research universities.

Case 2 is a large university with a comprehensive range of undergraduate and graduate program offerings. The university has an undergraduate enrolment of over 58,000 students (over 52,000 full-time), an enrolment that means that it has a larger number of undergraduate students than the top five ranked universities in the Shanghai Jiao University list ${ }^{2}$ combined (Harvard, Stanford, Berkeley, Cambridge, and MIT). The vast majority of these undergraduate students come from the greater metropolitan area in which the university is located, though the institution takes considerable pride in the fact that it is able to attract students with higher-secondary school grades than its peers in the same city. The university offers undergraduate programs on three campuses that serve different geographic regions of the city. The single largest source of university-operating revenue is the provincial government grant, which is awarded on the basis of an allocative formula that currently rewards enrolment growth. The university charges tuition fees, but fee levels are regulated by the provincial government, though there have been times when the government has loosened its controls over the level of professional and graduate program fees. Accessibility to postsecondary education is a provincial government priority, and the university is required to enter into a multi-year enrolment agreement with the province that encourages high participation rates in higher education.

Given these two brief scenarios, one might observe that the university in case 1 is more global in character and orientation. It is internationally recognized and ranked, it recruits international faculty and students, and it has acquired the resources and infrastructure necessary to sustain the sort of program of research that is associated with a major research university. The university in case 2 might be viewed as far more local in character and orientation. The university primarily attracts undergraduate students from the local metropolitan area, and is highly dependent on local, provincial government financial support in terms of public grants and tuition regulation. One might also assume that its mammoth undergraduate population is evidence of the institution's responsiveness to the local dimension, and to local government policies that favour accessibility. Given these brief descriptions, one might conclude that case 1 describes a more global university, and case 2 describes a more local or provincial institution. 
In reality, both case 1 and case 2 are descriptions of one university, the University of Toronto, and they were written to illustrate the conceptual complexities associated with attempting to classify institutions as global universities. The University of Toronto provides an interesting example of an institution that cannot be easily categorized, in part because it is problematic to assume that universities can simply be placed on a continuum that runs from local orientation to global presence. Canada's federal arrangements assign constitutional responsibility for higher education to the provinces, and in the absence of a national ministry of higher education, of anything resembling a national higher education framework, and of direct national government operating support to institutions, universities are funded and regulated locally through the provincial governments (Jones and Young, 2004; Jones, 2006; Fisher et al. , 2007; Shanahan and Jones, 2007). The provincial government of Ontario funds all universities on the basis of a common funding formula. There has been no formal institutional differentiation within the Ontario university sector, and in recent years enrolment growth has been the only means for increasing the level of government grants (Shanahan and Jones, 2007). In many important ways, the University of Toronto is a local institution that is funded by the government of Ontario to provide high levels of access to students from the surrounding geographic area. At the same time, the University of Toronto is a major international research university that is recognized as a global player in terms of research and graduate studies.

This positioning as both local and global is not without controversy. For more than 20 years the University of Toronto has argued, with little success, that its position as an international (or at least national) research university should be reflected in government-operating funding (Connell, 1987). It has argued that it should be funded as a national (or international) research university and be treated differently than its provincial university peers.

If universities can have both global and local dimensions, then we have to develop a more sophisticated understanding of the relationship between these two constructs; we cannot simply assume that there is a linear relationship that begins with the local and extends towards a global institution. There are, I believe, two simple ideas that may provide a useful way of studying and furthering our understanding of the global dimension. The first is the notion that there are local, national, and global elements of the external environment of the university. The second is to question whether the institution is the appropriate unit of analysis for the study of the globalization and the global dimension in higher education.

\section{The 'Glonacal'}

Simon Marginson and Gary Rhoades (2002) argue that comparative studies of higher education have tended to focus on national systems of higher education and scholars have been preoccupied with national policies and the role of markets in understanding these systems. This common approach has tended to understate, if not ignore, the importance of the local and global dimensions of the university's external environment. The local dimension relates to the pressure to address local interests and needs, such as the desire for highly specialized labour needs by local industry, the participation in local economic development initiatives, or the development of research projects or initiatives that focus on local problems or phenomena. The global dimension of the external environment has received even less attention as the focus on national systems has tended to limit the scope of analysis to the boundaries of the nation state, and yet there is now a 
considerable body of scholarship that draws attention to the role and influence of global organizations, such as the World Bank and the International Monetary Fund, on national higher education policy, especially in developing nations. OECD studies now play a role in framing national discussions in some jurisdictions. There has been a substantial increase in the number of global agencies, networks, and hybrid organizational arrangements.

Marginson and Rhoades (2002) use these three dimensions to develop what they call a 'glonacal' agency heuristic, using letters from the words global, national, and local to create this new term. Rather than viewing the relationship between local, national, and global as linear, they argue that these relationships are far more complex. Moving forward in the global dimension does not necessarily imply stepping back at the local or national level. In other words, Marginson and Rhoades would find nothing surprising in a university that is strongly engaged in both local and global dimensions of activity. A provincial university can be a global institution.

They use the glonacal construct as a component in the development of a heuristic that they believe represents an approach to comparative higher education analysis that avoids many of the failings associated with more traditional approaches. They argue that:

comparative higher education requires a new analytical framework, one that can take us beyond the hitherto almost exclusive reliance on national policy and national markets as the horizon of possibility. In using the nation-state as the dominant unit of analysis for international comparison, global forces remain shadowy, local variations are flattened our, and issues of 'street level' implementations are obscured. (Marginson and Rhoades, 2002, 305)

The solution, according to Marginson and Rhoades, is to study institutions of higher education as global agents; the focus is on agency both in terms of organizational activity and in terms of individual and collective agency. The result is a set of interconnected, three-dimensional hexagons operating on local, national, and global planes that are designed to replace Burton Clark's traditional triangle of coordination (1983) as a mechanism for studying and comparing national systems.

While Marginson and Rhoades focus primarily on the use of the heuristic as a mechanism for studying institutions, they also note that the heuristic could also be used to study programs or discipline areas, for example, the increasingly international dimension of, and international competition between, MBA programs. However, the innovative component of their heuristic is the three-plane emphasis on the local, national, and global dimensions, and they suggest that, given their broad definition of agency as referring 'to organized agencies and to the agency of human action' (p. 305), the heuristic can be used to look at different systems, institutions, or programs. In other words, they clearly recognize that the study of globalization in higher education is not simply an institutional phenomenon, but can (and does) impact and have implications for a range of actors and organizational units. The heuristic focuses on the multiple dimensions of the external environment, but it does not explicitly address the multiple dimensions of the internal environment.

\section{The Unit of Analysis}


Most of the discussions of globalization and higher education have focused on the institution, primarily the university, in the context of the higher education system. In many respects, the institution is the logical unit of analysis given the major reforms within many higher education systems during the last few decades. The massification of higher education led to major changes in the relationship between the university and the state. Reforms in many continental European jurisdictions have led to the development of new system-level frameworks, and a movement towards greater institutional autonomy.

Forty years ago Clark Kerr used the term 'multiversity' to describe the emergence of large comprehensive institutions that were, in many respects, holding companies for increasingly independent academic units (2001). The academic disciplines had been the dominant force in the development of the university through most of the 20th century, and the growth of the disciplinebased academic department had created an internal organizational unit that corresponded to what Becher would later refer to as the academic tribes and intellectual territories of higher education (1989). For Kerr, the independence of discipline-based departments in the context of increasingly large comprehensive universities was creating a situation where component parts of the institution could function without interacting with other component parts. The physics department determined the requirements and curriculum of the physics program. Members of the department were more likely to interact with scholars of physics in other countries, than to interact with professors of English or philosophy. More importantly, that professor's professional status and career progress was far more dependent on the judgement of academic peers within the discipline than with professors in other disciplines within the same institution. For Kerr, the university had become an organization of increasingly diverse, independent academic units held together by concerns about parking and a benevolent central administration.

For Burton Clark, the evolution of the multiversity raised the question of whether the institution was whole in the sense of being held together by anything resembling a common identity or organizational objectives. Clark concluded that the common purpose of universities was as 'places of inquiry' though this common frame surrounded an organization characterized by increasingly diverse, independent academic disciplines (1995). Becher's work on discipline differences provided a conceptual foundation for what became an expanding body of research illuminating the ways in which everything from career trajectories to teaching practices were related to, and differed by, academic disciplines. In order to understand changes within higher education, this body of scholarship suggests that scholars need to keep an eye on the understructure of the university; changes taking place within the disciplines and at the level of the department or faculty as a function of the growth of knowledge and increasing specialization might be having a significant impact on the day-to-day life of the university and the experience of its students and faculty in combination with, or perhaps even in resistance to, system-level or institutional reforms.

In many respects this perspective has been ignored within much of the contemporary discussion of internationalization and globalization in higher education. According to Jane Knight: Internationalization at the national, sector, and institutional levels is defined as the process of integrating an international, intercultural, or global dimension into the purpose, functions or delivery of postsecondary education. (Knight, 2004, 11) 
Internationalization, as a concept, presumes that higher education operates within the context of national governmental authority. Universities are located within nations, and they become internationalized by integrating extra-national dimensions (from other nations or cultures) into their functions or objectives. While there is clearly a recognition that internationalization is a process that must involve the classrooms and laboratories, and not just in the offices of the senior administration, there is a tendency to study and discuss internationalization using the institution as the major unit of analysis. For example, a recent study conducted by the International Association of Universities contributes to our understanding of internationalization by reporting on the results of a major study of institutions (Knight, 2006). We learn about the importance placed on international strategy, and other institution-level initiatives, such as the development of memoranda of understanding with other institutions. My point here is not to criticize this body of work; there are very logical reasons for focusing attention on institution-level perspectives, but rather to observe that since most of the attention has been focused on the institution, we know less about internationalization in terms of the understructure or about the complex interface between institutional and understructure processes.

There are a variety of definitions of globalization, but most definitions focus on the processes associated with the global flow of capital, trade, technology, communications, labour, and knowledge (Marginson, 2006, 2007). The complex implication for higher education of globalization has become a very important area of research, and there is considerable agreement that these implications have come to include an increasingly global market, and a repositioning of the university in the context of the knowledge economy (Jones et al. , 2005). Once again, it is the institution that has received the most attention in the analysis of globalization and higher education, in fact the emergence of global rankings of universities has led to a new body of research focusing on 'world-class' institutions, and in the differences between highly ranked institutions in terms of institutional strategies and approaches to globalization (Marginson and Sawir, 2006). There is a recognition that there may be differences in how globalization impacts different units within the university, but the literature tends to suggest that globalization 'happens' to institutions, and that it is the university, as an institution, that responds to, or takes proactive steps to position itself within, global forces. Jan Sadlak and Liu Nian Cai conclude that:

achieving 'world-class' status does not happen over-night, it is the result of a goal-directed, finetuned and continuous endeavour on the part of all those involved within the university setting, as well as those who create the policy framework and general climate in which such a status is both desirable and feasible. Overall, aiming for a 'world-class' moniker should not be considered an end in itself, but a well-thought-out option in the development of any higher education system and its institutions as a whole. (Sadlak and Liu, 2007, 23)

The image that emerges from this discussion is of the university as a largely hierarchical institution guided by a strategic central administrative infrastructure that is making decisions that will position the university in the context of increasingly complex global forces and markets.

In other words, a great deal of the literature on internationalization and globalization in higher education focuses on the institution as the unit of analysis, even though there is a substantive body of literature that illuminates substantive discipline differences within the university; it is quite logical to assume that there are major differences in the degree to which different units 
within the same institution are internationalizing, and the degree to which they are active in the global environment or responding to global pressures.

\section{The Global Higher Education Matrix}

I propose a shift in focus in the study of internationalization and globalization in higher education that incorporates multiple levels of authority within the higher education system, and a recognition that higher education operates on multiple dimensions. By combining the notion of levels of authority within higher education systems and Marginson and Rhoades' (2002) notion of multidimensionality to include a recognition of the local, national, and global planes of activity, one can develop a global higher education matrix

In his classic work on the organization of higher education, Burton Clark discussed issues of power and control in terms of levels of authority within the higher education system (1983). By comparing levels of authority in different systems, Clark illuminated substantive differences in power arrangements by system, for example, noting the high levels of authority associated with the state in the French system superstructure and at the understructure level, with limited authority at the institution or enterprise level. This image of the French system contrasted with the American experience, where much greater authority could be found at the institutional level.

Major national reforms to higher education have sometimes shifted the power and influence associated with the levels of authority within the higher education system. For example, Kells (1992) has used Clark's notion of levels of authority to illustrate major trends in power relationships in American, United Kingdom, and Continental European higher education systems. While these types of analyses are obviously overly simplistic, they do illuminate broad trends, and, most importantly, they demonstrate the importance of understanding changes in higher education in terms of the multiple layers of higher education activity (Amaral et al. , 2002). Assuming the existence of traditional hierarchical relationships between levels of authority within a higher education system is problematic.

It is also important to note that the multiple dimensions of higher education activity discussed by Marginson and Rhoades can also be seen at different levels of authority within the higher education system. Academic units at the understructure level may be operating at the local, national, and/or global dimensions ${ }^{3}$ with different units being oriented in different ways towards planes of activity. A university that may be a strong actor in the global dimension in terms of its institution-level activities may also have a large number of component parts that focus primarily on the local or national dimensions. In other words, the degree to which an academic unit is oriented towards each of the local, national, and global dimensions may be quite different than the ways in which other academic units in the same institutions are oriented towards these dimensions, and these dimensional profiles may be quite different than the ways in which the university, at the institutional level, participates in each plane of activity.

One also sees these multiple planes operating at the superstructure level as system-level authorities respond to local pressures for policy initiatives that will support provincial economic development, and/or participate in global initiatives related to, for example, regional trade 
agreements. Once again, this profile of activity at the superstructure level may be quite different than the profile that one might find at the institutional or understructure level.

The combination of these two notions, levels of authority and orientations towards different dimensions, can be combined to create a global higher education matrix (see Table 1 (See PDF) ). Beginning by focusing on the understructure as the primary unit of analysis, we can fill in the cells of the matrix with data on the intensity of orientation at each level for each dimension.

The global higher education matrix provides a framework for looking at globalization and internationalization in higher education without losing sight of the local and national dimensions that will continue to play a role within higher education systems. It also provides a framework for looking at how each level of authority is oriented towards these multiple dimensions.

At the same time, it is important to note that the number of column and row categories is arbitrary, and there may be good reasons to expand the number of categories along both dimensions. The analysis of a federal jurisdiction, for example, might benefit from studying the orientation at both the state and federal levels of authority, and adding another column in recognition that there may be another dimension of activity between the local and the national. In the case of Europe, one might want to consider a 'European' dimension that rests between the national and the global.

The greatest potential of the matrix is that it may provide a way of looking at some of the complex inter-relationships associated with the various cells. For example, to what extent can the development of a strong international strategy at the institutional level lead to a shift in the orientation towards the global dimension of understructure units? Can state-supported institutions be global in orientation while ignoring the local and national dimensions? This approach can also help us understand what may be very important differences between institutions that are (or aspire to be) world-class and global in orientation.

Oleksiyenko's (2008) recent work provides an interesting illustration of what one can learn from looking at internationalization at multiple levels of a higher education system. Oleksiyenko studied global portfolios and international partnership arrangements of five faculties within a major research university as well as institution-level international strategies and practices. He concluded that successful international partnerships at this university were 'developed and implemented at the grassroots level' $(2008,437)$ and that there were faculty-level concerns that strong, central institutional involvement in this area could limit or restrain understructure-level initiatives; '... central plans and strategies aimed at [supporting a] coordinated and integrated internationalization process, are often ignored and considered as ineffectual' (p. 437). According to the author, the limited institution-level orientation towards the global dimension can be partly explained by national policies that favoured international development activities over global science and technology initiatives. In short, while Oleksiyenko's work focuses only on the global dimension through a study of global portfolios and international partnerships, his findings illustrate important differences in orientation by level of authority (as well as between different units at the understructure level), and the complex inter-relationships between levels of authority. 
I began this paper by asking whether a provincial university can be a global institution. It is clear that universities operate on multiple planes, and that a university can be strongly local and global in orientation at the same time. I propose the global higher education matrix as a simple framework for understanding some of the complexities associated with the multi-dimensional nature of institutions, while also recognizing that there may also be important differences in dimensional orientations by levels of authority. The global higher education matrix may be a useful tool for studying internationalization and globalization in higher education by looking at some of the complex inter-relationships associated with the local, national, and global dimensions at different levels of authority within a higher education system.

\section{Acknowledgements}

An earlier version of this paper was presented at the World Universities Network seminar entitled 'Realizing the Global University', London, 14-15 November 2007. The author is grateful for the feedback that was provided by seminar participants.

\section{Notes}

${ }^{1}$ For example, the Times Higher Education Supplement and the Shanghai Jiao University rankings.

${ }^{2}$ Based on the 2007 ranking of the Academic Ranking of World Universities Project, Shanghai Jiao University, available at http://ed.sjtu.edu.cn/rank/2007/ARWU2007_Top100.htm. The undergraduate enrolment at each of the top five institutions was obtained from institutional and other reference websites.

${ }^{3}$ At some institutions there are multiple levels of international partnerships and initiatives. For example, the university may be involved in a range of international organizations and have partnership arrangements with peer institutions. Local units may also be involved in international organizations, or have a separate set of partnership arrangements with international peers. For example, the University of Toronto is now a member of the World Universities Network, and the Ontario Institute for Studies in Education of the University of Toronto is a member of an international alliance of research-intensive faculties of education. These international connections co-exist at multiple levels of the higher education system.

\section{References}

Amaral, A., Jones, G.A. and Karseth, B. (2002) 'Governing Higher Education: Comparing National Perspectives', in A. Amaral, G.A. Jones and B. Karseth (eds.) Governing Higher Education: National Perspectives on Institutional Governance, Dordrecht: Kluwer Academic Publishers, pp. 279-298.

Baker, D.P. and Lenhardt, G. (2008) 'The institutional crisis of the German research university', Higher Education Policy 21 (1): 49-64. 
Becher, T. (1989) Academic Tribes and Territories: Intellectual Enquiry and the Cultures of the Disciplines, Milton Keynes: The Society for Research into Higher Education and Open University Press.

Clark, B.R. (1983) The Higher Education System: Academic Organization in Cross-National Perspective, Los Angeles: University of California Press.

Clark, B.R. (1995) Places of Inquiry: Research and Advanced Education in Modern Universities , Los Angeles: University of California Press.

Connell, G.E. (1987) Renewal 1987: A Discussion Paper on the Nature and Role of the University of Toronto, Toronto: University of Toronto.

Fisher, D., Rubenson, K., Bernatchez, J., Clift, R., Jones, G., Lee, J., MacIvor, M., Meredith, J., Shanahan, T. and Trottier, C. (2007) Canadian Federal Policy and Post-Secondary Education, Vancouver, BC: Centre for Policy Studies in Higher Education and Training, University of British Columbia.

Jones, G.A. (2006) 'Canada', in J.F. Forest and P.G. Altbach (eds.) International Handbook of Higher Education, Dordrecht: Springer, pp. 627-645.

Jones, G.A., McCarney, P.L. and Skolnik, M.L. (2005) 'Introduction', in G.A. Jones, P.L. McCarney and M.L. Skolnik (eds.) Creating Knowledge, Strengthening Nations: The Changing Role of Higher Education, Toronto: University of Toronto Press, pp. 3-18.

Jones, G.A. and Young, S. (2004) 'Madly Off in All Directions: Higher Education, Marketization, and Canadian Federalism', in P. Teixeira, B.B. Jongbloed, D. Dill and A. Amaral (eds.) Markets and Higher Education: Rhetoric or Reality? , Dordrecht: Kluwer Academic Publishers, pp. 185-205.

Kells, H.R. (1992) Self-Regulation in Higher Education, London: Jessica Kingsley Publishers.

Kerr, C. (2001) The Uses of the University, 5th edn., Cambridge: Harvard University Press.

Knight, J. (2004) 'Internationalization remodeled: definitions, rationales, and approaches', Journal for Studies in International Education 8 (1): 5-27.

Knight, J. (2006) 'Internationalization of higher education: new directions, new challenges', 2005 IAU Global Survey Report, Paris: International Association of Universities.

Marginson, S. (2006) 'Globalisation, the "idea of a university" and its ethical regimes', Higher Education Management and Policy 19 (1): 31-46.

Marginson, S. (2007) 'The public/private divide in higher education: a global revision', Higher Education 53 (3): 307-333. 
Marginson, S. and Rhoades, G. (2002) 'Beyond national states, markets and systems of higher education: a glonacal agency heuristic', Higher Education 43 (3): 282-309.

Marginson, S. and Sawir, E. (2006) 'University leaders' strategies in the global environment: a comparative study of Universitas Indonesia and the Australian National University', Higher Education 52 (2): 343-373.

Mohrman, K. (2008) 'The emerging global model with Chinese characteristics', Higher Education Policy 21 (1): 29-48.

Newsweek International Edition . (2006) 'Complete list: the top 100 global universities', 13 August, http://www.msnbc.msn.com/id/14321230.

Oleksiyenko, A. (2008) 'Global portfolios and strategic international partnerships of a major research university', Unpublished doctoral dissertation, University of Toronto.

Sadlak, J. and Liu, N.C. (eds.) (2007) The World-Class University and Ranking: Aiming Beyond Status: Higher Education for a Knowledge Society, UNESCO, European Centre for Higher Education (CEPES), Cluj-Napoca: Presa Universitara Clujeana.

Shanahan, T. and Jones, G.A. (2007) 'Shifting roles and approaches: government coordination of postsecondary education in Canada from 1995 to 2006', Higher Education Research and Development 26 (1): 31-43. 